\title{
異なる波長を持つ波形が重畳する進行波列上の気流の数値計算*
}

\author{
木原 直人 ${ }^{* 1}$, 花崎 秀史 ${ }^{* 2}$, 平口 博丸 ${ }^{* 3}$
}

\section{Simulation of Airflow over Superposed Wave Train with Different Wave Lengths}

\author{
Naoto KIHARA *1, Hideshi HANAZAKI and Hiromaru HIRAKUCHI \\ ${ }^{* 1}$ Central Research Institute of Electric Power Industry \\ 1646 Abiko, Abiko-shi, Chiba, 270-1194 Japan
}

\begin{abstract}
Direct numerical simulations of the airflow over periodic superposed wave train with different wave lengths and phase velocities were carried out to investigate effects of airflow perturbation due to long waves on momentum transfer from the airflow to short waves. Both the short and the long waves travel in the streamwise direction of the airflow. The results show that the short wave-correlated component of the mean velocity and the pressure are affected by the long waves. The effects of the long wave on the momentum transfer from the airflow to the short waves depend on the wave ages of the short waves. For the low wave ages, it is guessed that the variance of the shear stress in the inner region due to the long wave-correlated momentum flux effects on the momentum transfer. On the other hand, for the middle wave ages, phase shift of the cat's eye caused by the mean velocity variance due to the long waves would effect on the momentum transfer.
\end{abstract}

Key Words : Wind Wave, Turbulent Flow, Swell, Air-Sea Interaction, Boundary Layer, DNS, Numerical Simulation

\section{1. 緒言}

大気・海洋間における運動量, 熱, 及び物質の交換は, 熱帯低気圧等のメソスケール気象擾乱の発達・減衰を 支配し ${ }^{(1)}$, 地球温暖化やエルニーニョ・南方振動等の気候システム変動に対しても重要な役割を持つ(2).これらの 大気・海洋間での相互作用はその境界に位置寸る風波を通して行われる，そのため，大気側及び海洋側における 風波による流れの擾乱は，これらの相互作用に対して影響を与える ${ }^{(3)-(5)}$.

大気から水面波への運動量輸送のメカニズムはこれまで調べられてきており，確からしいメカニズムがいくつ か提案されている(3)-(5). その中で風波の発達に関する主要なメカニズムとして, Miles ${ }^{(3)} の$ 臨界層機構と Belcher ら ${ }^{(5)}$ の非剥離シェルタリング機構が挙げられる，前者は，気流から風波への運動量の輸送が，気流の平均流速と風 波の位相速度が等しくなる臨界高さにおける流れに依存すると予測したものである，一方，後者は，気流から風 波への運動量の輸送が, 波面のごく近傍の inner region と呼ばれる境界層内のシアーにより決定されると予測した ものである.これらの運動量輸送機構の有効性は数值的又は観測的に検討されてきた. Sullivan ら ${ }^{(6)}$ は, 波長が単 一波長の正弦波の形状を持ち一定速度で進む進行波上の気流を 3 次元の直接数值計算(DNS)により調べることに より，臨界高さにおいて，進行波と相関がある流速成分が鉛直方向に顕著に変化することを示した. また，Hristov $ら^{(7)}$ は，海上での気流の観測結果を用いることにより，風波と相関がある流速成分が臨界高さにおいて顕著に変 化し，その構造が臨界層理論と一致することを示した。これらの数值計算及び観測による研究は，臨界層機構の 有効性を示している.

一方, Belcher $\check{(}^{(8)}$ は，気流から風波への運動量輸送機構が，気・液界面での摩擦速度 $u_{*}$ と風波の位相速度 $c$ の

\footnotetext{
* 原稿受付 2010 年 10 月 25 日

*1 正員, (財)電力中央研究所地球工学研究所（二 270-1194 千葉県我孫子市我孫子 1646)

*2 正員, 京都大学大学院 工学研究科

*3 (財)電力中央研究所地球工学研究所

E-mail: kihara@criepi.denken.or.jp
} 


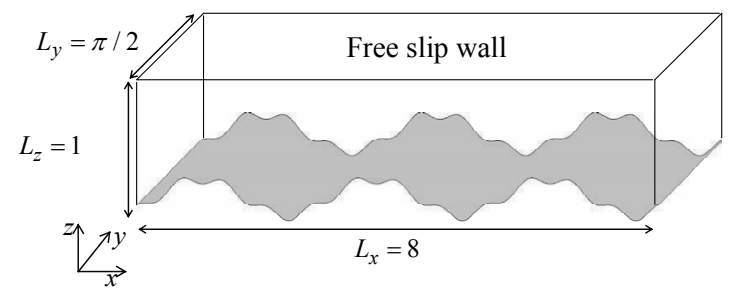

Fig. 1 Computational domain.

比である波齢 $\left(c / u_{*}\right)$ に依存した異なった機構に支配され，低波齢においては非剥離シェルタリング機構に，中波 齢においては臨界層機構に支配されると推測している．気流から進行波への運動量輸送を決定する波面上での圧 力分布が低波齢 $\left(c / u_{*}<4\right)$ においては波面近傍でのシアーによって決定され，一方中波齢 $\left(4 \leq c / u_{*} \leq 12\right)$ においては 臨界高さ近傍での流れによって決定されることが進行波上の気流の DNS により示されており 流から進行波への運動量輸送が，低波齢において非剥離シェルタリング機構に，中波齢において臨界層機構に支 配されることを意味する.

ただし，上述の運動量輸送機構は単一の波長での進行波を対象にして提案されたものであることに留意するべ きである. 実際の海洋上では複数の波長を持った進行波が重畳しているため，海洋上での気流から進行波への運 動量輸送を求める場合，上述の運動量輸送機構を直接適用することは適切でないと考えられる．従来，海洋上の 気流中の運動量輸送を予測するために, 風波上の境界層内の気流を鉛直 1 次元モデルにより表す研究が行われて きたが(10)-(14). これらの有効性は詳細には検証されていない.

また，複数の進行波が重畳した海面を対象とした研究の一つとして，遠方から伝播してきた低周波成分の水面 波であるう称りと風波が共存した海面上での運動量輸送について検討した研究があり，うねりが海面での運動量 フラックスに対して影響を与えることが報告されている(15)-(19). しかしながら，風波のような短波長の進行波上の 気流中の運動量輸送に対して，うねりのような長波長の進行波が与える影響には未だ不明な点が多い.

そこで本研究では，風波を模した短い波長の進行波と，波長がその 4 倍の進行波が重畳した 2 次元波形を持つ 水面上の気流場を，3 次元の DNS を実施することにより求め, 気流から短波長の進行波への運動量輸送に対して 長波長の進行波が与える影響について調べる。ここでは，短波長の進行波及び長波長の進行波が気流の流れ方向 一進行する場合を対象とする，過去に，進行速度 $c$ がゼロすなわち波齢 $c / u_{*}$ がゼロの条件で，短波長の波形と長 波長の波形が重畳した時間的に形状が変化しない波面上の気流を DNS で調べた研究があるが(17)-(18)，気流から進 行波への運動量輸送に対して波齢は重要なパラメーターである. そのため, 本研究では, 短波長及び長波長の進 行波をそれぞれの波長に対応した位相速度 $c$ で進行させ， 5 種類の短波長の進行波の波齢について，それぞれ計 算する.

\section{3 次元直接数値計算}

本研究で解析対象とする流れは，図 1 に示すような，短い波長の進行波とその 4 倍の波長を持つ進行波が重な った水面(下面)と，水平な摩擦無しの境界(上面)とに挟まれた領域内の気流である. 水平方向には周期境界条件を 仮定する.両方の波長の進行波は気流の流れ方向へ進行する. 進行波を深水近似でのストークス波と仮定すると, 波の位相速度 $c$ は波長 $k$ 及び重力加速度 $g$ を用いて $c=\sqrt{g / k}$ で与えられる. $\lambda$ を波長として波数は $k=2 \pi / \lambda$ で与 えられるため，短波長の進行波に比して，長波長の進行波は 2 倍の位相速度で進行する．本研究では，短波長の 進行波の位相速度と同じ速度で移動する系で計算する。したがって，下部境界の形状は時間的に変化する．また 流れは，一定の水平方向圧力勾配によって駆動されるとし，統計的に定常な乱流に対する計算を実施する．基礎 方程式は, 以下に示寸ナヴィエ・ストークス方程式と連続の式である.

$$
\frac{\partial u_{j}}{\partial t}+u_{l} \frac{\partial u_{j}}{\partial x_{l}}=-\frac{\partial p}{\partial x_{j}}+\frac{1}{\operatorname{Re}} \frac{\partial^{2} u_{j}}{\partial x_{l}^{2}}-\delta_{j 1}
$$




$$
\frac{\partial u_{j}}{\partial x_{j}}=0
$$

ここで, 添字 $j(=1,2,3)$ はそれぞれ流れ方向 $x$, スパン方向 $y$, 鉛直方向 $z$ を示寸. $z$ は平均水面を原点 $(z=0)$ にとる. また, $t$ は時間, $p$ は圧力, $\left(u_{1}, u_{2}, u_{3}\right)=(u, v, w)$ はそれぞれ $x, y, z$ 方向の流速である. 式(1)及び(2)における時間, 長 さ，流速，及び，圧力はそれぞれ $h / \hat{u}_{*}, h, \hat{u}_{*}$, 及び $\rho \widehat{u}_{*}{ }^{2}$ にって既に無次元化されている. ここで, $h$ は計算 領域の厚さである。 $\hat{u}_{*}$ は水面上での仮の摩擦速度であり， $\hat{u}_{*}$ を固定值として数值計算を実施した. その結果， $\hat{u}_{*}$ は, 後述する式(20)から得られる水面上での実際の摩擦速度 $u_{*}$ とほぼ同じ值になった. したがって, 以下では $\bar{u}_{*} の$ かわりに実際の摩擦速度 $u_{*}$ を用いて記述する. また, $\rho$ は空気の密度であり, $\operatorname{Re}\left(=u_{*} h / v\right)$ はレイノルズ数であり, $v$ は空気の動粘性係数である.

計算する座標系は以下の変換式により $(x, y, z)$ 座標系を一般座標系 $(\xi, \eta, \zeta)$ へ変換したものである.

$$
\begin{aligned}
& \xi=x-\mathrm{i} a_{1} \exp \left[\mathrm{i} k_{1} x\right] \exp \left\{-k_{1} z\right\}-a_{1}^{2} k_{1} \exp \left[\mathrm{i} 2 k_{1} x\right] \exp \left\{-2 k_{1} z\right\} \\
& -\mathrm{i} a_{2} \exp \left[\mathrm{i} k_{2}\left\{x-\left(c_{2}-c_{1}\right) t\right\}\right] \exp \left\{-k_{2} z\right\}-\mathrm{i} a_{2}^{2} k_{2} \exp \left[2 \mathrm{i} k_{2}\left\{x-\left(c_{2}-c_{1}\right) t\right\}\right] \exp \left\{-2 k_{2} z\right\} \\
& -\mathrm{i} a_{1} a_{2}\left(k_{1}+k_{2}\right) \exp \left[\mathrm{i} k_{1} x+\mathrm{i} k_{2}\left\{x-\left(c_{2}-c_{1}\right) t\right\}\right] \exp \left\{-\left(k_{1}+k_{2}\right) z\right\} \\
& \eta=y \\
& \zeta=z-a_{1} \exp \left[\mathrm{i} k_{1} x\right] \exp \left\{-k_{1} z\right\}-a_{1}^{2} k_{1} \exp \left[\mathrm{i} 2 k_{1} x\right] \exp \left\{-2 k_{1} z\right\} \\
& -a_{2} \exp \left[\mathrm{i} k_{2}\left\{x-\left(c_{2}-c_{1}\right) t\right\}\right] \exp \left\{-k_{2} z\right\}-a_{2}^{2} k_{2} \exp \left[2 \mathrm{i} k_{2}\left\{x-\left(c_{2}-c_{1}\right) t\right\}\right] \exp \left\{-2 k_{2} z\right\} \\
& -a_{1} a_{2}\left(k_{1}+k_{2}\right) \exp \left[\mathrm{i} k_{1} x+\mathrm{i} k_{2}\left\{x-\left(c_{2}-c_{1}\right) t\right\}\right] \exp \left\{-\left(k_{1}+k_{2}\right) z\right\}
\end{aligned}
$$

ここで, $\mathrm{i}$ は虚数単位であり, 物理変数としては式(3)の実部をとる. また, $a_{i}, k_{i}$ 及び $c_{i}$ は進行波の振幅, 波数, 及び位相速度である. 波形勾配は $a_{1} k_{1}=a_{2} k_{2}=0.1$ とした. なお, 以降, 短波長の進行波を短波, 長波長の進行波 を長波と呼ぶこととし，添字 $i=1$ は短波に関する值を，また， $i=2$ は長波に関する值を表す．変換式(3)では， 下面に対応する $\zeta=0$ において格子は水面に沿い, 上面に対応する $\zeta=1$ において格子はほぼ水平となる. 本研究 では水面形状が時間で変化するため, 移動座標系を用いる. $\zeta=0$ とおくことにより, 水面形 $z_{b o t}$ は以下のように 近似される。

$$
z_{\text {bot }} \approx a_{1} \cos \left(k_{1} x\right)+a_{2} \cos \left[k_{2}\left\{x-\left(c_{2}-c_{1}\right) t\right\}\right]+O\left(\left(a_{i} k_{j}\right)^{2}\right)
$$

ここで, 添字 bot は水面での值を示寸. 式(4)より, 水面形状は, 計算する系に対して, 静止している短波と $\left(c_{2}-c_{1}\right)$ の速度で $x$ 方向に移動する長波とが重畳した形状であることがわかる．また，この波形に対応した水面上での流 速を以下の式で近似し，下部境界条件として与える.

$$
\begin{aligned}
& u_{\text {bot }} \approx-c_{1}+u_{\mathrm{orb} 1}+u_{\mathrm{orb} 2} \\
& v_{\text {bot }} \approx 0 \\
& w_{\text {bot }} \approx w_{\mathrm{orb} 1}+w_{\mathrm{orb} 2}
\end{aligned}
$$

ここで， $u_{\mathrm{orb} i}$ 及び $w_{\mathrm{orb} i}$ は進行波の運動による速度成分であり，以下の式で与えられる.

$$
\begin{aligned}
& u_{\text {orb1 }}=a_{1} k_{1} c_{1} \cos \left(k_{1} x\right) \\
& u_{\text {orb2 }}=a_{2} k_{2} c_{2} \cos \left[k_{2}\left(x-\left(c_{1}-c_{2}\right) t\right)\right] \\
& w_{\text {orb1 }}=a_{1} k_{1} c_{1} \sin \left(k_{1} x\right) \\
& w_{\text {orb2 }}=a_{2} k_{2} c_{2} \sin \left[k_{2}\left(x-\left(c_{1}-c_{2}\right) t\right)\right]
\end{aligned}
$$

基礎方程式(1)及び(2)を式(3)で与えた一般座標系へ強保存形で変換すると次式が得られる.

$$
\frac{\partial J^{-1} u_{j}}{\partial t}+\frac{\partial}{\partial \xi_{l}} \hat{U}_{l} u_{j}=-\frac{\partial}{\partial \xi_{l}}\left(J^{-1} p \frac{\partial \xi_{l}}{\partial x_{j}}\right)+\frac{1}{\operatorname{Re}}\left(\frac{\partial^{2} u_{j}}{\partial \xi^{2}}+J^{-1} \frac{\partial^{2} u_{j}}{\partial \eta^{2}}+\frac{\partial^{2} u_{j}}{\partial \zeta^{2}}\right)
$$


Table 1 Wave ages used in this study, and their corresponding critical heights, roughness, phases of center of cat's eye, and total form drags.

\begin{tabular}{ccccccc}
\hline$c_{1} / u_{*}$ & $c_{2} / u_{*}$ & $\zeta_{+_{c 1}}$ & $\zeta_{{ }_{c 2}}$ & $\zeta_{+_{0}}$ & $\phi_{c 1} / \pi$ & $D_{p}$ \\
\hline \multicolumn{2}{c}{ Flat Channel } & - & - & 0.11 & & \\
1 & - & 1.17 & - & 0.16 & 0.89 & 0.11 \\
2 & - & 2.35 & - & 0.16 & 0.89 & 0.11 \\
4 & - & 5.16 & - & 0.17 & 0.87 & 0.13 \\
8 & - & 12.8 & - & 0.33 & 0.37 & 0.13 \\
12 & - & 22.3 & - & 0.14 & 0.37 & 0.022 \\
1 & 2 & 1.31 & 2.67 & 0.29 & 1.00 & 0.34 \\
2 & 4 & 2.88 & 6.28 & 0.36 & 0.94 & 0.33 \\
4 & 8 & 6.50 & 18.9 & 0.42 & 0.77 & 0.32 \\
8 & 16 & 16.3 & 212.1 & 0.36 & 0.27 & 0.076 \\
12 & 24 & 29.7 & - & 0.16 & 0.27 & -0.029 \\
\hline
\end{tabular}

$$
\frac{\partial J^{-1}}{\partial t}+\frac{\partial \hat{U}_{l}}{\partial \xi_{l}}=0
$$

ここで, $\left(\hat{U}_{1}, \hat{U}_{2}, \hat{U}_{3}\right)=(\hat{U}, \hat{V}, \hat{W})$ は $\left(\xi_{1}, \xi_{2}, \xi_{3}\right)=(\xi, \eta, \zeta)$ 方向流速の一般座標反変成分であり, 以下のように与えられ る.

$$
\hat{U}_{l}=J^{-1} u_{j} \frac{\partial \xi_{l}}{\partial x_{j}}+\frac{\partial \xi_{l}}{\partial t}
$$

$J$ はヤコビアンであり，以下の幾何学的保存則を満足する(20).

$$
\frac{\partial J^{-1}}{\partial t}+\frac{\partial}{\partial \xi_{l}}\left(J^{-1} \frac{\partial \xi_{l}}{\partial t}\right)=0
$$

幾何学的保存式(10)を連続式(8)に代入することにより次式が得られる.

$$
\frac{\partial U_{l}}{\partial \xi_{l}}=0
$$

ここで, $\left(U_{1}, U_{2}, U_{3}\right)=(U, V, W)$ は以下のように与えられる.

$$
U_{l}=J^{-1} u_{j} \frac{\partial \xi_{l}}{\partial x_{j}}
$$

数值計算においては，コロケート格子を用いた有限差分法により式(7)及び(11)の微分演算子を離散化することに より，流速及び圧力を時間発展させる(9).

レイノルズ数 Re は 300 とした. 計算領域は流れ方向, スパン方向, 鉛直方向をそれぞれ $L_{x}=8, L_{y}=\pi / 2, L_{z}=1$ とした．また，格子点数は，これら三方向に対して $360 \times 100 \times 256$ とした．波長 $\lambda_{1}$ は $2 / 3 ， \lambda_{2}$ はその 4 倍の $8 / 3$ と した．そして，短波の波齢 $c_{1} / u_{*}$ が $1,2,4,8,12$ の 5 ケースについて計算し，乱流統計量が定常になるまで時間発 展させた. なお，これらのケースでの長波の波齢 $c_{2} / u_{*}$ はそれぞれ $2,4,8,16,24$ である.

また，上述の数值計算との比較により，短波上の気流に対して長波が与える影響を調べるため，短波のみを用 いた単一波長の進行波列上の気流についても波齢 $c_{1} / u_{*}$ が $1,2,4,8,12$ の 5 ケースについて数值計算を実施した. 以降，単一波長の進行波列を単一波列，2 種類の波長を持つ進行波が重畳した進行波列を重畳波列と呼ぶ。さら に，進行波の有無による気流の影響を調べるため，レイノルズ数 Re が 300 での下部境界が平坦な平板上流れの 計算も実施した。ここで, 実施した数值計算の計算条件を表 1 に記述する. 表 1 には, 後述する臨界高さ $\zeta_{c i}$, 粗 度高さ $\zeta_{0}$, cat's eye の中心の位相 $\phi_{c 1}$, 及び, 圧力抵抗 $D_{p}$ も記述する. なお，添え字十を用いて，長さを $v / u * に$ より無次元化した值を表す. 
移動座標系における 3 次元直接数值計算の精度を確認するため，進行波と同じ速度で移動する系においてレイ ノルズ数 Re が 150 における波齢 $c / u_{*}=0,2,4,8,10,12,16,20$ での単一波列上の気流の 3 次元直接数值計算を実施 している Kihara ら ${ }^{(9)}$ と同じ条件の下で, 静止系での数值計算を実施した. Kihara ら ${ }^{(9)}$ の数值計算では, 水面の形 状及び座標系は時間的に変化しない，一方，静止系での数值計算では，水面の形状及び座標系は時間的に変化す る. そして，その計算結果をKihara ら ${ }^{(9)}$ の結果と比較した，その結果，平均流速や圧力分布，レイノルズ応力等 の分布がほぼ一致することを確認した。

\section{3. 統計量の定義}

2 次元的な波面上の気流では，流れ $(x)$ 方向に，水面波形と同じ波数の変化が平均流に生じ，水面波形と同じ進 行方向に, 同じ位相速度で移動する. 以下の解析では, 物理量 $q$ を, 時間 $t$, 流れ方向座標 $\xi$, スパン方向座標 $\eta$ で平均することにより得られるアンサンブル平均 $\langle q\rangle^{i}(\zeta)$ と, 計算領域内にある $N_{i}$ 個の波の同一位相 $\phi_{i}\left(0 \leq \phi_{i} \leq 2 \pi\right)$ における值について平均をとった位相平均 $q^{i}\left(\phi_{i}, \zeta\right)$ からアンサンブル平均 $\langle q\rangle^{i}$ を引いた波状成分 $\tilde{q}^{i}\left(\phi_{i}, \zeta\right)$ と, 乱流 成分 $q^{\prime}(\xi, \eta, \zeta, t)$ とに分ける(22).

$$
\begin{aligned}
& q(\xi, \eta, \zeta, t)=\langle q\rangle^{1}(\zeta)+\tilde{q}^{1}\left(\phi_{1}, \zeta\right)+\tilde{q}^{2}\left(\phi_{2}, \zeta\right)+q^{\prime}(\xi, \eta, \zeta, t) \\
& \dot{q}^{i}\left(\phi_{i}, \zeta\right)=\frac{1}{N_{i} L_{y} \Delta T} \sum_{n=0}^{N_{i}-1} \int Q_{i}\left(x=\lambda_{i}\left(n+\frac{\phi_{i}}{2 \pi}\right), y, \zeta, t\right) d y d t \\
& \langle q\rangle^{i}(\zeta)=\frac{1}{L_{x} L_{y} \Delta T} \int Q_{i}(x, y, \zeta, t) d x d y d t \\
& \tilde{q}^{i}\left(\phi_{i}, \zeta\right)=\bar{q}^{i}\left(\phi_{i}, \zeta\right)-\langle q\rangle^{i}(\zeta)
\end{aligned}
$$

ここで, $\Delta T$ は平均寸る時間間隔， $N_{i}$ は計算領域内の進行波の数であり，短波では $N_{1}=12$, 長波では $N_{2}=3$ であ る. $Q_{i}$ は進行波と同じ速度で移動する系における物理量 $q$ の值であり, 本研究では短波と同じ速度で移動する系 で計算しているため $Q_{1}=q$ である. なお本研究では, 波面近傍での統計量を得るために, 直角座標系の $z$ 面上で はなく $\zeta$ 面上で平均することにより平均量を計算している.

\section{4. アンサンブル平均流速分布}

本計算で用いた全ての波齢における，静止系に対するアンサンブル平均流速 $\langle u\rangle^{1}+c_{1}$ の鉛直分布を図 2 に示す. 平板上流れの平均流速 $\langle u\rangle$ も同時に図示寸る. また, 対数領域における平均流速の大きさを理解しやすくするた めに, $\zeta_{+}=200$ において対数則を仮定することにより次式から求めた粗度高さ $\zeta_{+0}$ を表 1 に示す.

$$
\zeta_{+0}=200 \exp \left[-\kappa\left(\langle u\rangle^{1}+c_{1}\right)\right]
$$

ここで， $\kappa(=0.4)$ はカルマン定数である. また，平均流速勾配の波齢依存性を明瞭にするため，平板上流れでの 平均流速勾配に対する進行波上の気流での平均流速勾配の比を図 3 に示寸. 単一波列上の流れでは, 中波齢 $\left(c_{1} / u_{*}=4\right.$ 及び 8$)$ において, 平均流速勾配に特徵的な波齢依存性が $\zeta_{+}<30$ で見られる(図 $\left.3(\mathrm{a})\right) . c_{1} / u_{*}=4$ では, 平 板上流れと比較して， $\zeta_{+}=20$ 近傍での平均流速勾配が大きい.この波齢では, $\zeta_{+}<10$ において平均流速勾配が 平板上流れよりも小さく, そこでの平均流速が小さいため, 結果的に, $\zeta_{+}>50$ において平均流速は平板上流れと ほぼ同じ大きさになる.一方， $c_{1} / u_{*}=8$ では，平板上流れと比較して， $\zeta_{+}<30$ において平均流速勾配が小さい(図 3 (a)). その結果, $\zeta_{+}>50$ において平均流速は平板上流れよりも低くなっている. 低波齢 $\left(c_{1} / u_{*}=1,2\right)$ 及び $c_{1} / u_{*}=12$ では，平均流速及び平均流速勾配が平板上流れとほぼ同様に分布する. 平均流速分布に見られる波齢に依存した これらの特徵は, Sullivan ら ${ }^{(6)}$ 及び Kihara ら ${ }^{(9)}$ の結果と定性的に一致する.

重畳波列上の流れでは，短波の波齢 $c_{1} / u_{*}$ が同一の単一波列上の流れと比較して， $\zeta_{+}<20$ において平均流速勾 配が小さく(図 $3(\mathrm{~b}))$, その結果, 対数領域 $\left(\zeta_{+}>50\right)$ での平均流速が低くなっている(図 $\left.2(\mathrm{~b})\right)$. 特に $c_{1} / u_{*}=1,2$ 及 

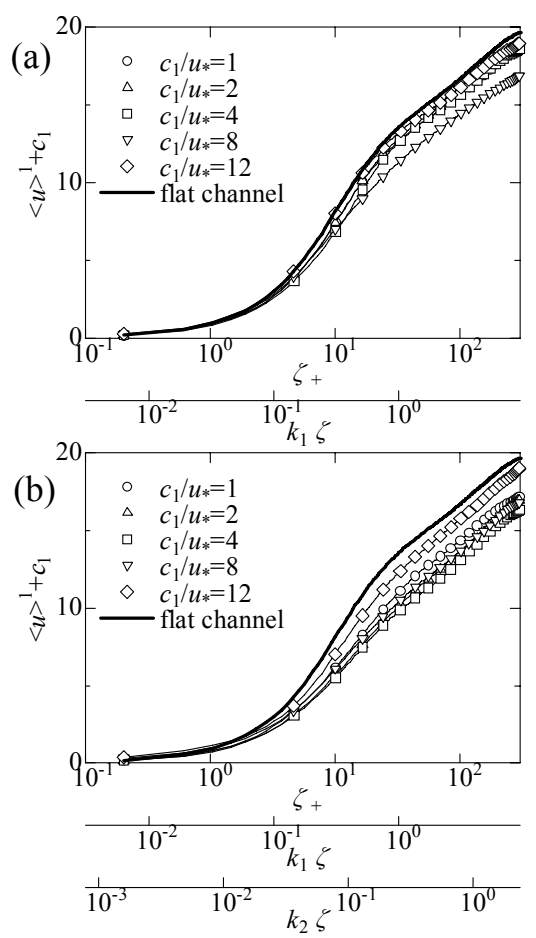

Fig. $2 \zeta$-direction distributions of the

ensemble-averaged streamwise velocities, for (a) monochromatic wave train and (b) superposed wave train. Bold solid line denotes the flat channel flow.
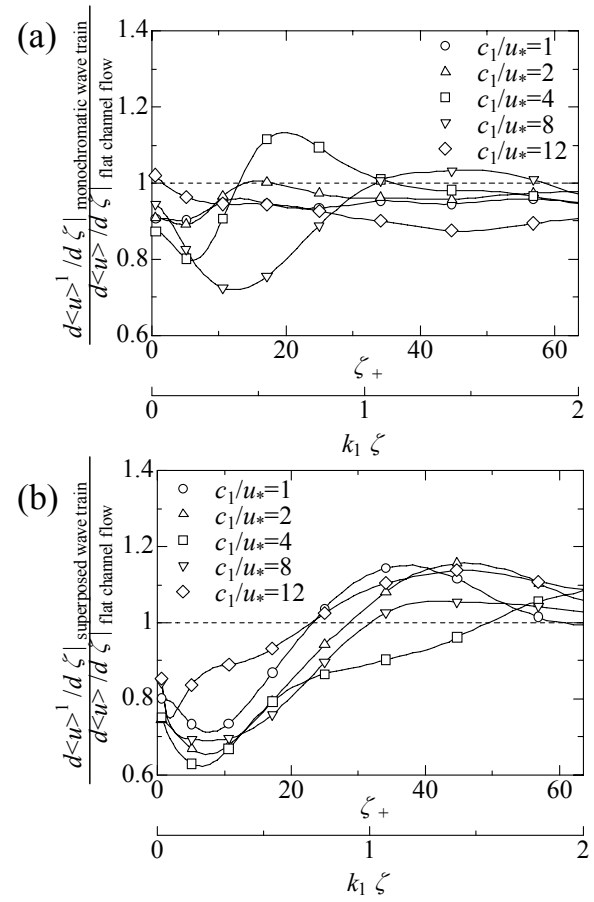

Fig. $3 \zeta$-direction distributions of ratios of the vertical gradient of the ensemble-averaged streamwise velocities for the monochromatic wave train (a) and superposed wave train (b) to that of the flat channel flow.

び 4 において平均流速の低下は著しく, 一方， $c_{1} / u_{*}=8$ 及び 16 において平均流速の低下は小さい. 第 6 章の後 半で述べるが，重畳波列上の流れの平均流速と単一波列上の流れの平均流速とに見られた違いは，長波に起因し た応力の影響によって引き起こされる.

\section{5. 圧力及び流線の分布}

単一波列，及び，重畳波列の短波と相関がある位相平均成分に対応する流線，及び，圧力の波状成分の等高線 を図 4 に示す．図 4 は短波と同じ速度で移動する系で示している，そのため，短波の位相速度と気流の平均流速 が一致する臨界高さの下側では，流れが気流の逆向きになる．そして，臨界高さの近傍において流線の閉曲線で ある cat's eye が見られる. 図 4 の流線から視覚的に見積もった cat's eye の中心の位相 $\phi_{c 1}$ を表 1 に示す.

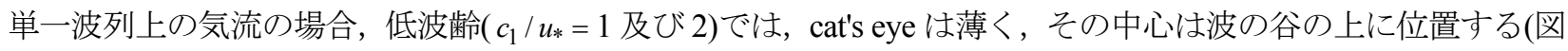
4 (a)-(b)). 最も低い波齢である $c_{1} / u_{*}=1$ において圧力の最小值は波頭の風下側に位置し, 最大值は波頭の風上側 に位置する，これらの波齢では，波齢が増加するにつれて圧力の位相が風下側へ移動する. Kihara ら $^{(9)}$ は, 低波 齢において, 波面近傍でのシアーがそこでの圧力分布の位相を決定する最も支配的な要因であることを示してお り，このことは，波面近傍での圧力分布が cat's eye を含んだ波面近傍に位置する inner region と呼ばれる境界層内 でのシアーによって決定される非剥離シェルタリング機構が，気流から進行波への運動量輸送に対して支配的で あることを示唆する. 一方, 中波齢 $\left(c_{1} / u_{*}=4,8\right.$ 及び 12$)$ では, cat's eye の中心の位相は波齢により異なり, $c_{1} / u_{*}=4$ では波の谷に， $c_{1} / u_{*}=8$ 及び 12 では波頭のやや風下に位置する(図 4 (c)-(e)). そして, 低波齢における圧力の位 相の波齢依存性と異なり，中波齢での圧力の位相は波齢が増加するにつれて風上側へ移動する．また， cat's eye の中心の位相と, 波面上での圧力の最小值がほぼ同じ位相に位置する. 波面上での圧力の位相が cat's eye の位置 によって決定されることは, 波面上での圧力分布が cat's eye を囲む臨界層内での流れによって決定される臨界層 機構が，気流から進行波への運動量輸送に対して支配的であることを意味寸る ${ }^{(9)}$. 

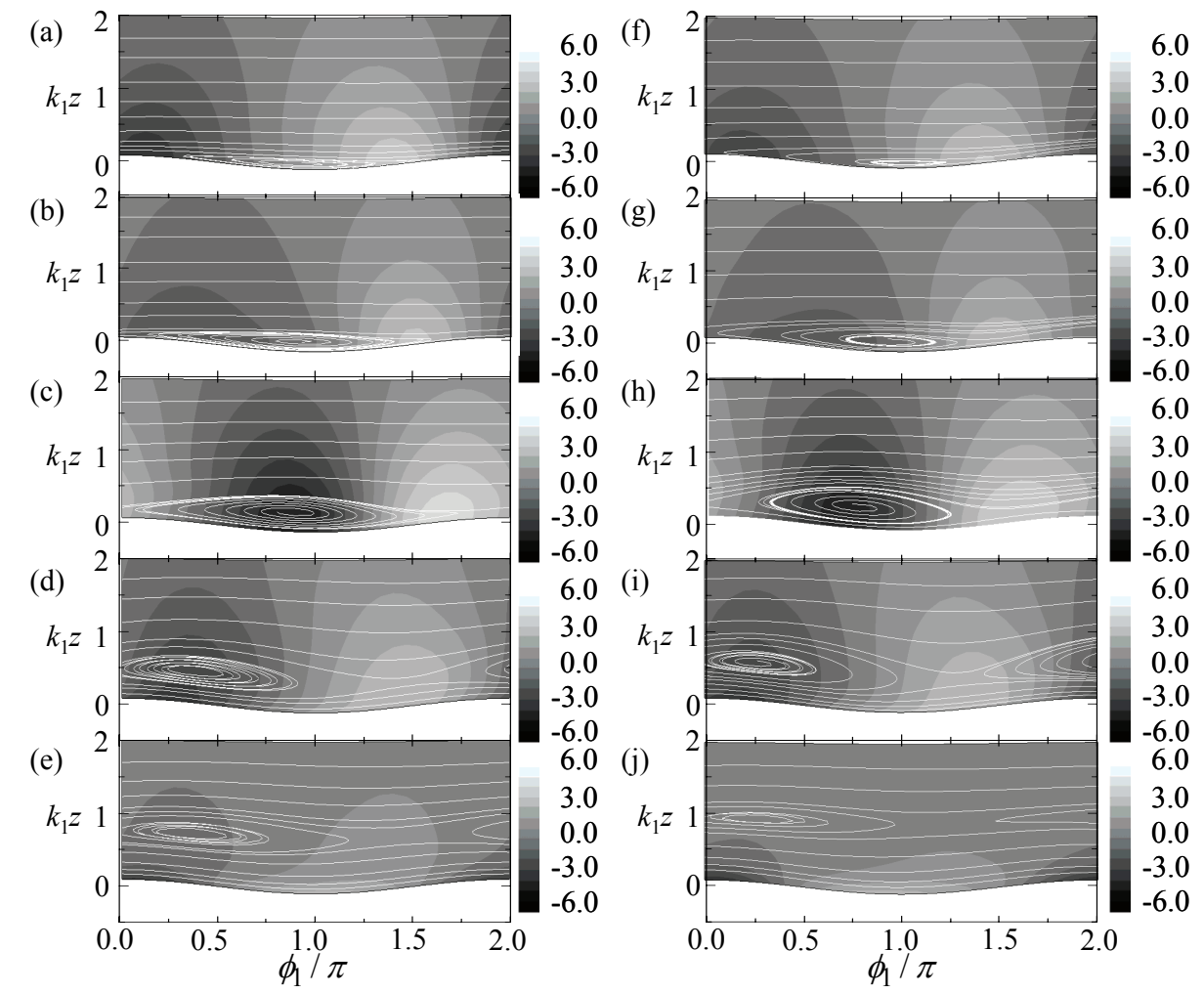

Fig. 4 The phase-averaged streamlines (white lines), and the wave-correlated pressure $\tilde{p}^{1}$ for the monochromatic wave train of (a) $c_{1} / u_{*}=1$, (b) $c_{1} / u_{*}=2$, (c) $c_{1} / u_{*}=4$, (d) $c_{1} / u_{*}=8$ and (e) $c_{1} / u_{*}=12$, and those correlated with short waves for the superposed wave train (f) $c_{1} / u_{*}=1$, (g) $c_{1} / u_{*}=2$, (h) $c_{1} / u_{*}=4$, (i) $c_{1} / u_{*}=8$, (j) $c_{1} / u_{*}=12$.

Kihara ら ${ }^{(9)}$ は, 圧力分布に対して cat's eye が与える役割について以下のように調べている. 式(13)-(16)を用いて 流速及び圧力を分解し, 直角座標系におけるナヴィエ・ストークス方程式(1)に代入し, 微小な項を無視すること により，圧力の波状成分は次式で近似される.

$$
\frac{\partial \tilde{p}^{1}}{\partial x} \approx-\langle u\rangle^{1} \frac{\partial \tilde{u}^{1}}{\partial x}-\tilde{w}^{1} \frac{\partial\langle u\rangle^{1}}{\partial z}-\frac{\partial{\widetilde{u^{\prime} w^{\prime}}}^{1}}{\partial z}+\frac{1}{\operatorname{Re}} \frac{\partial^{2} \tilde{u}^{1}}{\partial z^{2}}
$$

臨界高さでは, $\langle u\rangle^{1}=0$ となるため右辺第 1 項がゼロになる. したがって, 式(18)は, 臨界高さでの圧力の位相が 鉛直流速の波状成分 $\tilde{w}^{1}$ 及びシアーの波状成分(第 3 項及び第 4 項)によって決定されることを示している．短波の 位相速度で移動する座標系における cat's eye の中心の位相 $\phi_{c 1}$ と, 臨界高さにおける鉛直流速の波状成分 $\tilde{w}^{1} の$ 基 本モードの位相 $\varphi_{\tilde{w} 1}$ との間には $\phi_{c 1}=\varphi_{\tilde{w} 1}+\pi / 2$ の関係がある. 寸なわち, 中波齢において, 臨界高さでの圧力の最 小值が cat's eye の中心に位置することは, 圧力の位相に対して式(18)の右辺第 2 項, 寸なわち流れの波状成分が 支配的であることを示しており，臨界層機構が，気流から進行波への運動量輸送に対して支配的であることを意 味する(9). 一方，低波齢において，臨界高さでの圧力の最小值が cat's eye の位置のみによって決定されないこと は，圧力の位相に対して流れの波状成分だけでなくシアーも寄与することを示しており，臨界層機構が運動量輸 送に対して支配的でないことを意味する。

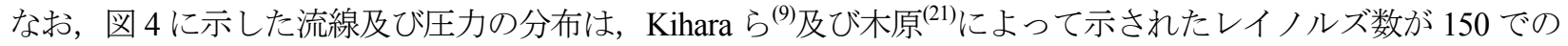
単一波列上の気流でのそれらと非常に類似している. これは, 本研究における $v / u_{*}$ で無次元化した波長 $\lambda_{+1}$ が, 彼らの $\lambda_{+1}$ と一致するためだと推測される. ここで, $R e=150$ での cat's eye の中心の位相を表 2 に示す. $R e=150$ での計算結果からも，低波齢において，cat's eye の中心は波齢に依存せず，波の谷の上に位置し，中波齢 $\left(c_{1} / u_{*}=4\right.$, 5, 6, 8, 10 及び 12)において, cat's eye の中心は波齢が増加するにつれて波の谷のやや風上から波頭のやや風下へ移 動することがわかる. 
Table 2 Wave ages used in Kihara et al. ${ }^{(9)}$ and Kihara ${ }^{(21)}$, and their corresponding phases of center of cat's eye and form drags.

\begin{tabular}{ccc}
\hline$c_{1} / u_{*}$ & $\phi_{c 1} / \pi$ & $D_{p}$ \\
\hline 2 & 0.94 & 0.11 \\
4 & 0.94 & 0.13 \\
5 & 0.77 & 0.16 \\
6 & 0.58 & 0.18 \\
8 & 0.33 & 0.12 \\
10 & 0.30 & 0.055 \\
12 & 0.30 & 0.027 \\
16 & 0.50 & -0.009 \\
20 & - & -0.027 \\
\hline
\end{tabular}

重畳波列上の気流の場合，流線及び圧力は単一波列上の気流でのそれらと概ね類似した分布を持つ.ただし， 前章で示したように，重畳波列での平均流速は，単一波列でのそれよりも小さいため，重畳波列での短波に対す る臨界高さ $z_{c}$ は, 単一波列での $z_{c}$ よりも高くなる. それに伴って重畳波列での cat's eye は, 単一波列のケースと 比較して波面から離れた高さに位置する(図 4). また，cat's eye の中心の位相に着目すると，低波齢 $\left(c_{1} / u_{*}=1\right.$ 及び

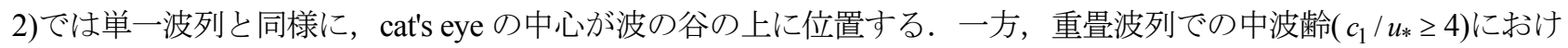
る cat's eye の位相を同一波齢 $c_{1} / u_{*}$ での単一波列のそれと比較すると(表 1 参照), 重畳波列での cat's eye の中心の 位相が単一波列でのそれよりもやや風上側に位置することがわかる. 寸なわち，これらのことより，長波には， 短波の位相速度で移動する座標系での流線に見られる cat's eye の波面からの距離及び中心の位相を変化させる働 きがあることがわかる。

\section{6. 短波上の気流から進行波への運動量輸送に対して長波が与える影響}

式(13)-(16)を用いて流速及び圧力を分解し，それを運動方程式(7)に代入することにより，進行波上の気流中の 運動量フラックスが得られる(日).

$$
\tau_{\text {total }}=\underbrace{\left\langle\left\langle\tilde{u}^{i} \widetilde{W}^{i}\right\rangle^{1}-\left\langle{\overline{J^{-1}}}^{i} \bar{\zeta}_{x}^{i} \frac{i}{p}\right\rangle^{1}\right.}_{\text {wave-correlated stress }}-\underbrace{\left\langle u^{\prime} W^{\prime}\right\rangle^{1}}_{\text {turbulent stress }}+\underbrace{\frac{1}{\operatorname{Re} \frac{\partial\langle u\rangle^{1}}{\partial \zeta}}}_{\text {viscous stress }}+\underbrace{\zeta}_{\text {external force }}
$$

ここで， $\tau_{\text {total }}$ は全運動量フラックス，右辺第 1 項及び第 2 項は波に起因した応力，第 3 項は乱流応力，第 4 項は 粘性応力，第 5 項は水平方向の圧力勾配に起因した外力項である.

波面上 $(\zeta=0)$ における式(19)で表される運動量フラックスは, 気流から液側へ輸送される運動量を表す. 波面 上では, 式(19)の乱流応力項, 外力項, 及び, 波に起因した応力のうち右辺第 1 項がゼロになるため, 気流から 液側へ輸送される運動量は圧力抵抗 $D_{p}$ と摩擦抵抗 $D_{f}$ の和で表される.

$$
\tau_{\text {total }}=\underbrace{-\left\langle{\overline{J^{-1}}}^{i} \bar{\zeta}_{x}^{i}{ }^{i}\right\rangle^{1}}_{\text {Form drag }}+\underbrace{\frac{1}{\operatorname{Re}} \frac{\partial\langle u\rangle^{1}}{\partial \zeta}}_{\text {Friction drag }} \equiv u_{*}^{2}
$$

式(20)の右辺第 1 項は短波又は長波に起因した圧力抵抗 $D_{p i}$ である. 圧力抵抗 $D_{p i}$ は気流から進行波への運動量輸 送を表し, 摩擦抵抗 $D_{f}$ は気流から水中の平均流れへの運動量輸送を表す。したがって, 気流から進行波への運動 量輸送は波面上での圧力分布に依存する. 単一波列上の気流での圧力抵抗 $D_{p 1}$, 及び, 重畳波列上の気流での短 波及び長波に起因した圧力抵抗 $D_{p 1}, D_{p 2}$ とその和である全圧力抵抗 $D_{p}$ を図 5 に示す. 図 5 には, $\mathrm{Re}=150$ での進 行波上の気流での圧力抵抗 ${ }^{(9)(21)}$ もあわせて図示する。 以下では，まず単一波列上の気流での圧力抵抗について議 論し，その後，重畳波列上の気流での圧力抵抗について議論する. 


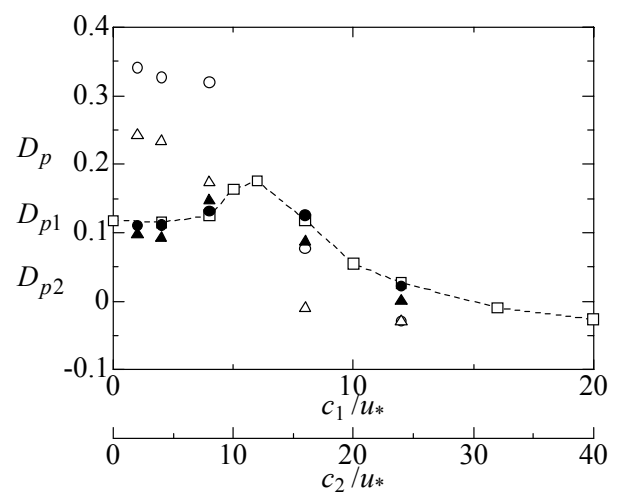

Fig. 5 Form drags. $\bigcirc$ denote the total form $\operatorname{drag} D_{p}$ for the superposed wave train; $\boldsymbol{\Delta}$, the short wave-correlated form $\operatorname{drag} D_{p 1}$; $\triangle$, the long wave-correlated form $\operatorname{drag} D_{p 2} ; \boldsymbol{O}$, the form drag for monochromatic wave train under $\operatorname{Re}=300 ; \square$, the form drag for monochromatic wave train under $\mathrm{Re}=150^{(9)(21)}$.

\section{$6 \cdot 1$ 単一波列上の気流での圧力抵抗}

本研究での単一波列上の気流での圧力抵抗の波齢依存性は $\mathrm{Re}=150$ での圧力抵抗のそれと定量的にほぼ一致す る. また, 図 2 及び図 4 で示した本研究での単一波列上の気流での平均流速, 流線及び圧力の分布もまた, $\mathrm{Re}=150$ でのそれらと類似していることから， Re=150 での圧力抵抗の波齢依存性を用いることにより，本研究で実施し ていない波齢 $\left(c_{1} / u_{*}=0,5,6,10,16,20\right)$ での圧力抵抗の波齢依存性を補間できると考えられる. そのため，本研究 での単一波列上の結果及び $\mathrm{Re}=150$ での結果を用いることにより, 単一波列での圧力抵抗 $D_{p}$ の波齢依存性は以 下のようにまとめられる. 低波齢 $\left(c_{1} / u_{*} \leq 2\right)$ では, 圧力抵抗がほぼ一定である. 一方, 中波齢 $\left(4 \leq c_{1} / u_{*} \leq 12\right)$ では, 圧力抵抗が複雑な波齢依存性を持ち，波齢が増加するにつれて圧力抵抗は一旦増加し， $c_{1} / u_{*}=6$ において最大に なる. そして，さらに波齢が増加すると圧力抵抗は減少する．高波齢 $\left(c_{1} / u_{*}>12\right)$ では，波齢が増加するにつれて 圧力抵抗がゆるやかに減少し， $c_{1} / u_{*}=16$ で負になる.

ここで, 複雑な波齢依存性を持つ中波齢での圧力抵抗について議論する. 式(20)より圧力抵抗は次式で近似さ れる.

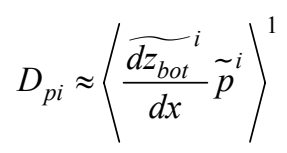

この式は，圧力抵抗が波面上での圧力変動の振幅，及び，その位相と波形の位相との関係によって決定されるこ とを意味する. 例えば, $x$ 方向の圧力変動の振幅が一定の場合, $d \widetilde{z_{b o t}} / d x$ が最大になる $\phi_{1}=1.5 \pi$ に圧力の最大が 位置し, $d \widetilde{z_{b o t}} i d x$ が最小になる $\phi_{1}=0.5 \pi$ に圧力の最小が位置する時, 圧力抵抗は最大になる. ここで, 波面上で の圧力変動の振幅，及び位相を調べるために，短波と相関がある圧力の波状成分 $\tilde{p}^{1}$ を次式のように分解する.

$$
\tilde{p}^{1}=\sum_{n=1}^{N}\left|\hat{p}_{n}\right| \cos \left(n k_{1} x-\varphi_{\tilde{p} n}\right)
$$

ここで, $\left|\hat{p}_{n}\right|$ 及び $\varphi_{\tilde{p} n}\left(0 \leq \varphi_{\tilde{p} n}<2 \pi\right)$ は波数 $n k_{1}$ のモードの振幅及び位相である. なお，圧力においては， $n=1$ の基 本モードの成分が最も支配的であるため，以下では基本モードのみを用いて議論する.

まず, 波面上での圧力の振幅について調べるため, 短波と相関がある波面上での圧力の基本モードの振幅 $\left|\hat{p}_{1}\right|$ を 図 6 に示す. なお, 図 6 には $R e=150$ での結果 ${ }^{(9)(21)}$ も図示する. 本研究での単一波列での圧力の基本モードの振 幅 $\left|\hat{p}_{1}\right|$ は, Re=150 での結果とほぼ同じ值である. そのため, 本研究での結果に加えて, $\mathrm{Re}=150$ での結果も用い ることにより，|$\left|\hat{p}_{1}\right|$ の波齢依存性について述べる. 図 6 より，中波齢 $\left(4 \leq c / u_{*} \leq 12\right)$ での $\left|\hat{p}_{1}\right|$ は波齢が増加するにつ れて $5 \leq c_{1} / u_{*} \leq 10$ においてやや減少し， $c_{1} / u_{*} \geq 10$ においてやや増加するものの，低波齢及び高波齢での $\left|\hat{p}_{1}\right|$ と比 較して波齢依存性は弱い.このことは, 中波齢における圧力抵抗の波齢依存性に対して, 波面上での圧力の振幅 の波齢依存性が与える影響は小さく, 圧力の位相の波齢依存性が与える影響が支配的であることを意味する. 


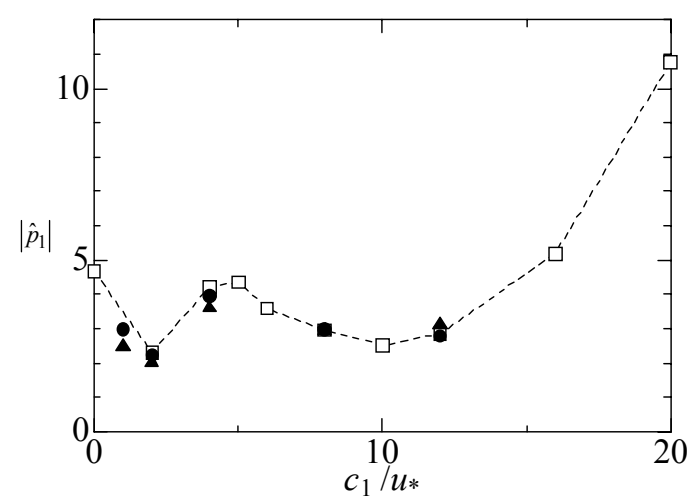

Fig. 6 Amplitude of the fundamental mode of wave-correlated pressure on the wave train. denote the short wave-correlated pressure for superposed wave train; $\boldsymbol{O}$, the wave-correlated pressure for monochromatic wave train under $\mathrm{Re}=300 ; \square$, the wave-correlated pressure for monochromatic wave train under $\mathrm{Re}=150^{(9)(21)}$.

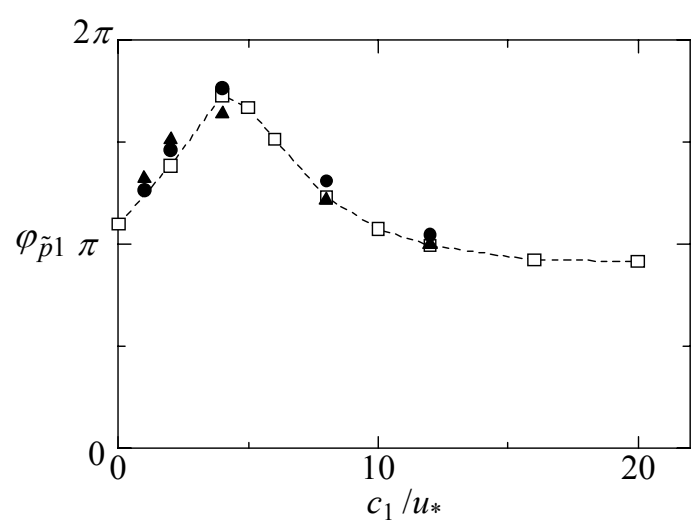

Fig. 7 Phase of the fundamental mode of wave-correlated pressure on the wave train. $\boldsymbol{\Delta}$ denote the short wave-correlated pressure for superposed wave train; , the wave-correlated pressure for monochromatic wave train under $\mathrm{Re}=300 ; \square$, the wave-correlated pressure for monochromatic wave train under $\mathrm{Re}=150^{(9)(21)}$

次に, 波面上での圧力の位相について調べる. 短波と相関がある波面上での圧力の基本モードの位相 $\varphi_{\tilde{p} 1}$ を図 7 に示す. 図 7 には $R e=150$ での結果 ${ }^{(9)(21)}$ も図示する. 圧力の基本モードの位相 $\varphi_{\tilde{p} 1}$ においても, 本研究での単一 波列での結果は $\operatorname{Re}=150$ での結果とほぼ同じ值である. そのため, 本研究での結果に加えて, $R e=150$ での結果 も用いることにより， $\varphi_{\tilde{p} 1}$ の波齢依存性について述べる. 中波齢 $\left(4 \leq c / u_{*} \leq 12\right)$ では，波面上での圧力の位相 $\varphi_{\tilde{p} 1}$ は 波齢が増加寸るにつれて $1.8 \pi$ から $\pi$ 一減少寸る. これは波面上での圧力の最小值の位相が，波の谷のやや風上か ら波頭に向かって風上側へ移動することを意味する. そのため, $4 \leq c_{1} / u_{*} \leq 6$ においては波齢が増加するにつれて 波面上での圧力の最小值の位相が $\phi_{1}=0.5 \pi$ に近づく. その結果, 圧力抵抗が波齢にともなって増加したと考えら れる. さらに波齢が増加寸ると $\left(6<c_{1} / u_{*} \leq 12\right)$, 波面上での圧力の最小值の位相は $\phi_{1}=0.5 \pi$ から離れる. その結果, 圧力抵抗は波齢にともなって減少したと考えられる.

\section{$6 \cdot 2$ 重畳波列上の気流での圧力抵抗}

前節で示した図 5 より, 重畳波列での短波に起因した圧力抵抗 $D_{p 1}$ と単一波列での圧力抵抗 $D_{p}$ との差は, 波齢 に依存することがわかる. 低波齢では，重畳波列での短波に起因した圧力抵抗 $D_{p 1}$ は単一波列での $D_{p}$ よりも $10 \%$ 程度小さい. 中波齢では, 重畳波列での $D_{p 1}$ は単一波列での $D_{p}$ と比較して, $c_{1} / u_{*}=4$ において大きいが, $c_{1} / u_{*}=8$ 及び 12 において小さい.

一方, 重畳波列での長波に起因した圧力抵抗 $D_{p 2}$ は低波齢から中波齢 $c_{2} / u_{*} \leq 8\left(c_{1} / u_{*} \leq 4\right)$ において有意な正の值 であり，高波齢 $c_{2} / u_{*} \geq 16\left(c_{1} / u_{*} \geq 8\right)$ においてほぼゼ口になる. 重畳波列での全圧力抵抗は，短波に起因した圧力 抵抗 $D_{p 1}$ と長波に起因した圧力抵抗 $D_{p 2}$ の和であるため, 単一波列での $D_{p}$ と比較して $c_{1} / u_{*} \leq 4$ において大きく, $c_{1} / u_{*} \geq 8$ において小さい.

以下では, 気流から短波への運動量輸送に対して長波が与える影響について議論するため, 重畳波列での短波 に起因した圧力抵抗 $D_{p 1}$ と単一波列での圧力抵抗 $D_{p}$ との間に見られた違いに着目する. まず低波齢 $\left(c_{1} / u_{*}=1\right.$ 及 び2)に関して述べ, その後, 中波齢 $\left(c_{1} / u_{*}=4,8\right.$ 及び 12)に関して述べる.

低波齢では, 既往の研究(5)(8)(9) 及びこれまでの検討から, 気流から進行波への運動量輸送が非剥離シェルタリン グ機構に支配されると考えられる.この機構では, 波面近傍に位置する inner region 内でのシアーによって圧力分 布が波頭の風上側と風下側で非対称になることにより，気流から進行波へ運動量が輸送される ${ }^{(5)}$. すなわち，輸 送される運動量は inner region 内でのシアーの強さに依存する. 式(19)より, 進行波が存在することにより, 波に 起因した応力によって乱流応力と粘性応力の和であるシアーは平板上流れのシアーと異なった分布になる. 単一 

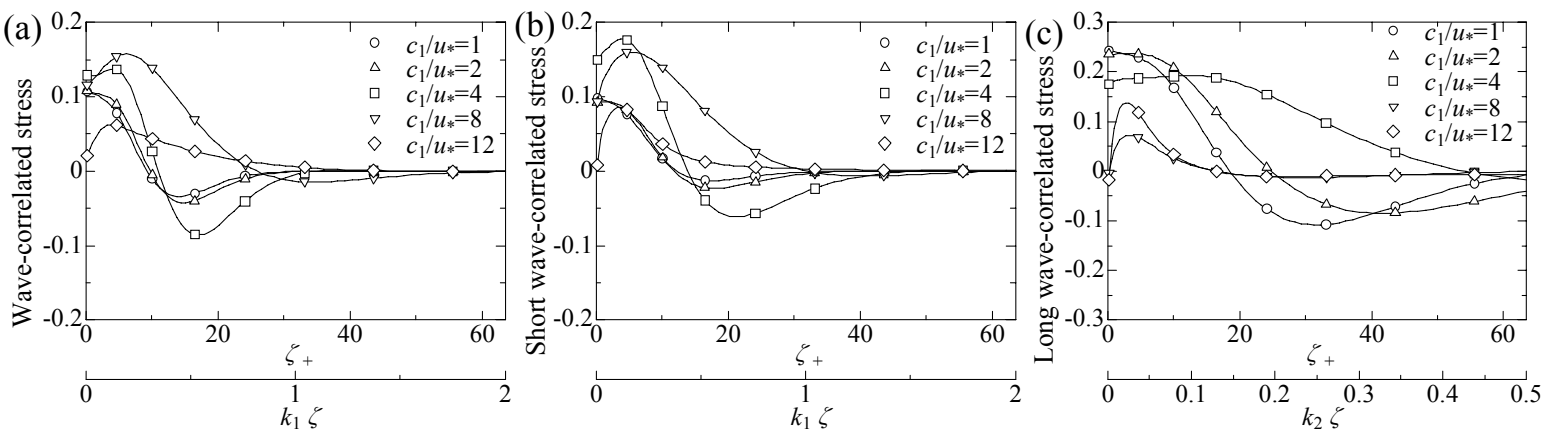

Fig. $8 \zeta$-direction distributions of (a) wave-correlated stress for monochromatic wave train, and (b) the short wave-correlated stress, and (c) the long wave-correlated stress for superposed wave train.

波列上の気流では，短波に起因した応力がシアーに影響を与え，重畳波列上の気流では，短波に起因した応力に 加えて長波に起因した応力がシアーに影響を与える.

ここで, 波に起因した応力の鉛直分布を図 8 に示す. 図 8 には, 単一波列での波に起因した応力, 重畳波列で の短波及び長波に起因した応力の分布を図示している．なお，定義より，波面上 $(\zeta=0) て ゙ は$ 波に起因した応力は 圧力抵抗と一致する．単一波列の場合，低波齢において，波面から離れるにつれて波に起因した応力は低下し， $\zeta_{+} \approx 15$ で最小になり, その後増加してゼロに向かう.これらの波齢では, $\zeta_{+}>10$ において波に起因した応力は 負になり， $\zeta_{+} \approx 30$ でほぼゼロになる(図 8 (a)). 寸なわち，進行波が存在しない平板上流れと比較して，シアーは

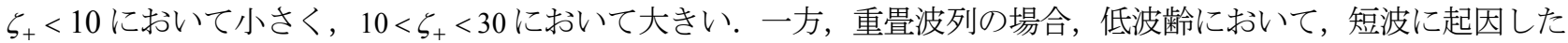
応力は単一波列でのそれと類似した分布を持つ (図 $8(\mathrm{~b}))$. 長波に起因した応力は，低波齢において，波面から離 れるにつれて低下し， $\zeta_{+} \approx 20$ で負になる(図 $\left.8(\mathrm{c})\right)$. したがって，重畳波列での短波に起因した応力と長波に起因 した応力の和である波に起因した全応力は, 単一波列での波に起因した応力と比較して, $\zeta_{+}<20$ において大きい. その結果, 重畳波列でのシアーは単一波列でのシアーよりも $\zeta_{+}<20$ において小さくなる. Meirink ${ }^{(23)}$ 及び Kihara ら ${ }^{(9)}$ に倣い， inner region の厚さ $\zeta_{I D}$ を計算した結果， $c_{1} / u_{*}=1$ において $\zeta_{+I D}=16, \quad c_{1} / u_{*}=2$ において $\zeta_{+I D}=19$ で あった．したがって，inner regionの内部では，重畳波列でのシアーは単一波列でのシアーよりも小さく，このこ とは inner region 内のシアーを減少させる働きが長波にあることを意味する. その結果, 気流から短波への運動量 輸送に対して仕事をするシアーが小さくなるため, 重畳波列での短波に起因した圧力抵抗 $D_{p 1}$ は単一波列での $D_{p}$ よりも小さくなったと推測される.

次に，中波齢 $\left(c_{1} / u_{*}=4,8\right.$ 及び 12$)$ における気流から短波への運動量輸送に対して長波が与える影響について議 論する. 中波齢では，重畳波列での短波に起因した圧力抵抗 $D_{p 1}$ が単一波列での $D_{p}$ よりも $c_{1} / u_{*}=4$ において大き く, 一方, $c_{1} / u_{*}=8$ 及び 12 において小さい. 重畳波列での短波に起因した圧力抵抗 $D_{p 1}$ と単一波列での $D_{p}$ の関 係について，波面上での圧力の位相に着目して以下で議論する.

図 7 より，中波齢において，重畳波列での波面上の圧力の位相は，単一波列でのそれよりもやや風上側に移動 する. したがって, 重畳波列における $c_{1} / u_{*}=4$ での波面上の圧力最小值の位相は, 単一波列における $c_{1} / u_{*}=4$ で のそれよりも $\phi_{1}=0.5 \pi$ に近づくが，重畳波列における $c_{1} / u_{*}=8$ 及び 12 での波面上の圧力最小值の位相は単一波列 における $c_{1} / u_{*}=8$ 及び 12 でのそれよりも $\phi_{1}=0.5 \pi$ から離れる. 6.1 節で述べたように, 中波齢において圧力抵抗 の波齢依存性は波面上での圧力の位相の波齢依存性に支配されるため，中波齢における重畳波列での圧力抵抗は $c_{1} / u_{*}=4$ において単一波列での圧力抵抗よりも増加し， $c_{1} / u_{*}=8$ 及び 12 において単一波列での圧力抵抗よりも 減少したと考えられる.

最後に，これらの波齢における波面上での圧力の位相に対して長波が与える影響について調べる．上述したよ うに図 7 より，重畳波列での波面上の圧力の位相は，単一波列でのそれよりもやや風上側に移動する．第 5 章で 述べたように，これらの波齢では，圧力の位相が cat's eye の中心の位相によって決定される. また, 長波には cat's eye の中心の位相を変化させる働きがあり, 重畳波列での cat's eye の中心の位相は, 単一波列でのそれよりもや や風上側に位置する(表 1). 長波による cat's eye の位相の変化は, 図 7 に見られた波面上での圧力の位相の変化に 
対応している.このことは, 長波の働きによる cat's eye の中心の位相の変化が, 短波への運動量輸送に対して影 響を与えたことを意味する.

なお，上述したように，単一波列上の流れでは短波に起因した応力が波面近傍でのシアーに対して影響を与え るが，重畳波列上の流れでは，短波に起因した応力に加えて，長波に起因した応力もまたシアーに対して影響を 与える. 図 8 に示したように, 波面近傍での全応力に対する長波に起因した応力の寄与は, $c_{1} / u_{*}=1,2$ 及び 4 に おいて大きい. したがって, 重畳波列の場合には, 単一波列の場合と比較して, 波面近傍でのシアーが減少する. その結果, そこでの平均流速勾配が低下し, 対数領域における平均流速が低下した(図 2,3). このことは, 長波が 存在することによって生じる気流の擾乱が平均流速分布を変化させることを意味する．また，この長波の働きに よる平均流速の変化が cat's eye の位置及び位相，すなわち，短波一の運動量輸送に対して影響を与えたと考えら れる.

\section{7. 結語}

本研究では, 風波を模した短波長の進行波と, 波長がその 4 倍の長波長の進行波が重畳した 2 次元波形を持つ 水面上の気流場を, 3 次元の DNS を実施することにより求め, 気流から短波長の進行波一の運動量輸送に対して 長波長の進行波が与える影響を調べた.

その結果, 気流から短波への運動量輸送に対して長波が与える影響は, 波齢によって異なることがわかった. 低波齢の場合, 長波に起因した応力による inner region 内のシアーの変化が, 短波への運動量輸送に対して影響を 与えたと推測される，一方，中波齢の場合，長波が存在することによって生じる気流の擾乱が平均流速分布を変 化させる. この平均流速の変化に伴って, 短波の位相速度で移動する座標系での流線に見られる cat's eye の位相 が変化し，その結果，短波への運動量輸送に対して影響を与えたと考えられる.

本研究ではレイノルズ数 Reが 300 での低波齡流れを対象としており, 実際の海上での気流と比べてレイノル ズ数が非常に小さい. ただし, 本研究で検討した気流から短波への運動量輸送に対して長波が与える影響の物理 的な解釈はレイノルズ数にあまり依存しないものと考えられる. しかしながら, 定量的な評価をするには, 高レ イノルズ数での検討が必要となるため, 今後は LES や現地観測を実施することにより, 高レイノルズ数での検討 を実施する予定である.

\section{謝 辞}

本研究を実施するにあたり, (財)電力中央研究所の服部康男主任研究員から適切で有意義な助言を頂いた. こ こに深く謝意を表する．また，查読を通して查読者の先生方から貴重な御意見・御助言を頂いた．ここに深謝す る.

\section{文献}

(1) Emanuel, K.A., "An air-sea interaction theory for tropical cyclones. Part I: Steady-state maintenance", Journal of Atmospheric Science, Vol. 43, No. 6 (1986), pp. 585-604.

(2) Latif, M. and Barnett, T.P., "Causes of decadal climate variability over the North Pacific and North America", Science, Vol. 266, No. 5185 (1994), pp. 634-637.

(3) Miles, J.W., "On the generation of surface waves by shear flows", Journal of Fluid Mechanics, Vol. 3, No. 2 (1957), pp. 185-204.

(4) Phillips, O.M., "On the generation of waves by turbulent wind", Journal of Fluid Mechanics, Vol. 2 (1957), pp. 417-445.

(5) Belcher, S.E., and Hunt, J.C.R., "Turbulent shear flow over slowly moving waves", Journal of Fluid Mechanics, Vol. 251 (1993), pp. 109-148.

(6) Sullivan, P.P., McWilliams, J.C. and Moeng, C., "Simulation of turbulent flow over idealized water waves", Journal of Fluid Mechanics, Vol. 404 (2000), pp. 47-85. 
(7) Hristov, T.S., Miller, S.D. and Friehe, C.A., "Dynamical coupling of wind and ocean waves through wave-induced air flow", Nature, Vol. 422, No.6 (2003), pp. 55-58.

(8) Belcher, S.E., and Hunt, J.C.R., "Turbulent flow over hills and waves", Annual Review of Fluid Mechanics, Vol. 30 (1998), pp. 507-538.

(9) Kihara, N., Hanazaki, H., Mizuya, T. and Ueda, H., "Relationship between airflow at the critical height and momentum transfer to the traveling waves", Physics of Fluids, Vol. 19, No.1 (2007), 015102.

(10) Janssen, P.A.E.M., "Wave-induced stress and the drag of air flow over sea waves", Journal of Fluid Mechanics, Vol. 117 (1982), pp. 493-506. .

(11) Chalikov, D., and Makin, V.K., "Models of the wave boundary layer”, Boundary Layer Meteorology, Vol. 56 (1991), pp. 83-99.

(12) Makin, V.K., Kudryavtsev V.N., and Mastenbroek, C., "Drag of the sea surface”, Boundary Layer Meteorology, Vol. 73 (1995), pp. 159-182.

(13) Hara, T. and Belcher, S.E., "Wind profile and drag coefficient over mature ocean surface wave spectra", Journal of Physical Oceanography, Vol. 34, No. 11 (2004), pp. 2345-2358.

(14) Kihara, N. and Hirakuchi, H., "A model for air-sea interaction bulk coefficient over a warm mature sea under strong wind", Journal of Physical Oceanography, Vol. 38, No. 6 (2008), pp. 1313-1326.

(15) Drennan, W.M., Taylor, P.K. and Yelland, M.J., "Parameterizing the sea surface roughness", Journal of Physical Oceanography, Vol. 35, No. 5 (2005), pp. 835-848.

（16）丹野賢二，小森 悟，“風波気液界面近傍の乱流構造と物質移動に及ぼすうねりの影響”，日本機械学会論文集 B 編, Vol. 70, No. 691 (2004), pp. 644-649.

(17) 今城貴徳，長田孝二，小森悟, “波状壁面上の乱流構造と抗力に及ぼすうねりの影響”, 日本機械学会論文集 B 編, Vol. 71, No. 706 (2005), pp. 1504-1510.

(18) 今城貴徳, 山本敏之, 黒瀬良一, 小森悟, “波状壁面上の乱流構造と抗力に及ぼす斜めうねりの影響”, 日本機械学会 論文集 B 編, Vol. 73, No. 731 (2007), pp. 1518-1524.

(19) Sullivan, P.P., Edson, J.B., Hristov, T. and McWillams, J.C., "Large-eddy simulations and observations of atmospheric marine boundary layers above nonequilibrium surface waves”, Journal of Atmospheric Science, Vol.65, No. 4 (2008), pp. 1225-1245.

(20) Thomas, P.D. and Lombard, C.K., "Geometric conservation law and its application to flow computations on moving grids", AIAA Journal, Vol. 17, No.10 (1979), pp. 1030-1037.

(21) 木原直人, “気・液界面近傍の乱流構造と輸送機構に関する数值的研究”, $\mathrm{PhD}$ thesis (2006), p. 115.

(22) Hussain, A.K.M.F. and Reynolds, W.C., "The mechanics of an organized wave in turbulent shear flow", Journal of Fluid Mechanics, Vol. 41, No.2 (1970), pp. 241-258.

(23) Meirink, J. F., and Makin, V.K., "Modeling low-Reynolds-number effects in the turbulent air flow over water waves", Journal of Fluid Mechanics, Vol. 415 (2000), pp. 155-174. 